Special issue of the 3rd International Conference on Computational and Experimental Science and Engineering (ICCESEN 2016)

\title{
Determination of Radiation Shielding of Concrete Produced from Portland Cement with Boron Additives
}

\author{
M. Davraz ${ }^{a}$, H.E. PehlivanoĞLu ${ }^{b}$, Ş. KilinÇARslan ${ }^{a, *}$ And İ. AKKurT ${ }^{c}$ \\ ${ }^{a}$ Suleyman Demirel University, Deymam Department, Isparta, Turkey \\ ${ }^{b}$ İzmir Metropolitan Municipality, Zonning and Supervision Department, İzmir, Turkey \\ ${ }^{c}$ Suleyman Demirel University, Physics Department, Isparta, Turkey
}

\begin{abstract}
Concrete is a material which is widely used for neutron shielding in such building constructions as nuclear power stations, particle accelerators and medical hospitals. Concrete is very significant for neutron shielding, because is contains some elements which help to moderate very penetrative fast neutrons. Boron increases the neutron shielding effectiveness of concretes. Boron can be added to concrete in different ways, by addition of boron to the water, used in concrete, or by addition of boron containing natural minerals. In this study, three samples of concrete were produced using $\mathrm{B}_{2} \mathrm{O}_{3}$ additives material, boron-modified active belite and Portland cement. Neutron absorption coefficients of the produced three different types of concrete samples were obtained through experiments. It is concluded that the addition of boron to concrete is an alternative option to be used for the purposes of neutron shielding.
\end{abstract}

DOI: 10.12693/APhysPolA.132.702

PACS/topics: 61.43.Gt, 28.41.QB

\section{Introduction}

Radiation adversely affects human health and so, its level must be as low as possible $[1,2]$. Therefore, several methods have been developed for protection from radiation. Among these methods the shielding is the most effective one [3]. Boron has a high affinity for oxygen, forming strong covalent boron-oxygen bonds in compounds known as borates [4]. Boron is also the only light element with two abundant isotopes, B10 and B11 [5]. It has a large capture cross-section, that makes it an excellent neutron absorber [6].

Radioactive wastes of nuclear power plants are mixed with high-concentration borate solutions (as a constituent material of neutron shields, because of its high absorption of neutrons) and then these mixtures are solidified by using cement, to be stored underground [7]. The improvements and additional features provided by boron compounds to concrete and other cementitious composites are closely related to $\mathrm{B}_{2} \mathrm{O}_{3}$ concentrations of used boron compounds $[8,9]$.

\section{Materials and methods}

\subsection{Materials}

In the present study, three different types of concrete were manufactured. Portland CEM I 42.5R and boron modified active belite $(\mathrm{BAB})$ cements were used in the produced samples. These two types of concrete series were employed for quality control. Portland CEM I 42.5R type of cement was used in the producion of the third

* corresponding author; e-mail: seref@tef.sdu.edu.tr sample, containing anhydrous boric acid $\mathrm{B}[\mathrm{OH}]_{3}(\mathrm{BA})$, as well as sodium aluminate $\mathrm{NaAlO}_{2}$ (SA), which was used for extending of the duration of the concrete setting. The physical and chemical properties of PC and BB cements, which were used as the binding material, are given in Table I.

Limestone with four different grain sizes was used as the aggregate. Grain size analysis was performed on aggregates according to TS 706, EN 12620 and TS 802 standards. Aggregates forms CT1 (coarse 22.4-8 mm), CT2 (medium 8-4 mm), CT3 (fine 4-2 mm) and CT4 (sand stone $2-0 \mathrm{~mm}$ ), groups and grain sizes of these groups were analyzed. Values of $D_{\max }=22.4 \mathrm{~mm}$ and 15-18 cm were aimed for aggregate mixture and slump value, respectively. For reducing the ratio w/c, slump was fixed and hyper plasticizer was employed in proportion with the weight of cement amount. Besides, fly ash (FA) was included into the mixture as a mineral additive, for reducing the dosage of cement, ensuring the activity of the plasticizer and for enhancing the workability, while keeping the strength constant. The amounts of the components added to $1 \mathrm{~m}^{3}$ mixtures in the manufacturing process of concrete are presented in Table II.

\subsection{Methods}

After 28 days of curing of concrete samples of series $\mathrm{PC}, \mathrm{BAB}$ and $\mathrm{BSA}$, the neutron absorption experiments were conducted at Gamma Spectroscopy Laboratory located at Süleyman Demirel University, Faculty of Arts and Sciences, Department of Physics. Measurements were performed using a neutron dosimeter. Linear absorption coefficients, which were obtained for neutrons with energy of $2.2 \mathrm{MeV}$, emitted by ${ }^{252} \mathrm{Cf}$ neuron source, were utilized for determining the radiation absorbing properties of concretes. 
TABLE I

The physical and chemical properties of $\mathrm{PC}$ and $\mathrm{BAB}$ cements.

\begin{tabular}{|c|c|c|c|c|c|}
\hline \multicolumn{3}{|c|}{ Clinker components } & \multicolumn{3}{|c|}{ Cement physical properties } \\
\hline Components [\%] & $\mathrm{PC}$ & $\mathrm{BAB}$ & & $\mathrm{PC}$ & $\mathrm{BAB}$ \\
\hline $\mathrm{SiO}_{2}$ & 20.52 & 20.37 & Volumetric expansion [mm] & 1 & 0 \\
\hline $\mathrm{Al}_{2} \mathrm{O}_{3}$ & 4.00 & 4.45 & Fineness $(90 \mu)$ & 0.1 & 0.1 \\
\hline $\mathrm{Fe}_{2} \mathrm{O}_{3}$ & 3.45 & 3.27 & Slightness $(200 \mu)$ & 1.1 & 1.8 \\
\hline $\mathrm{CaO}$ & 64.28 & 58.19 & Specific surface area $\left[\mathrm{cm}^{2} / \mathrm{g}\right]$ & 3340 & 3560 \\
\hline $\mathrm{MgO}$ & 1.63 & 4.70 & Initial setting time [min] & 185 & 220 \\
\hline $\mathrm{SO}_{3}$ & 2.53 & 3.08 & Final setting time [min] & 240 & 265 \\
\hline $\mathrm{Na}_{2} \mathrm{O}+\mathrm{K}_{2} \mathrm{O}$ & 1.35 & 1.50 & Specific gravity & 3.12 & 2.98 \\
\hline $\mathrm{B}_{2} \mathrm{O}_{3}$ & 0.00 & 1.12 & Flexural strength [MPa, 2 days] & 4.5 & 2.5 \\
\hline $\mathrm{CaO}$ (Free) & 1.81 & 0.63 & Flexural strength [MPa, 7 days] & 5.8 & 4.1 \\
\hline L.O.I. & 2.72 & 4.02 & Flexural strength [MPa, 28 days] & 7.2 & 6.0 \\
\hline \multicolumn{3}{|c|}{ Clinker phases [\%] } & Pressure strength [MPa, 2 days] & 11.7 & 11.7 \\
\hline $\mathrm{C}_{3} \mathrm{~S}$ & - & 56.66 & Pressure strength [MPa, 7 days] & 39.3 & 23.2 \\
\hline $\mathrm{C}_{2} \mathrm{~S}$ & 66.23 & 17.65 & Pressure strength [MPa, 28 days] & 51.0 & 38.6 \\
\hline $\mathrm{C}_{3} \mathrm{~A}$ & 7.86 & 6.33 & \multicolumn{3}{|l|}{ Other properties } \\
\hline $\mathrm{C}_{4} \mathrm{AF}$ & 14.01 & 12.03 & $\mathrm{Cl}^{-}$ & 0.000 & 0.006 \\
\hline
\end{tabular}

TABLE II

Amount of the concrete components added to $1 \mathrm{~m}^{3}$ mixture $[\mathrm{kg}]$.

\begin{tabular}{|c|c|c|c|c|c|c|c|}
\hline \multirow{2}{*}{\multicolumn{2}{|c|}{ Components }} & \multicolumn{2}{|c|}{$\mathrm{PC}$} & \multicolumn{2}{|c|}{ BAB } & \multicolumn{2}{|c|}{ BSA } \\
\hline & & $\begin{array}{c}\text { Weight } \\
{[\mathrm{kg}]}\end{array}$ & $\begin{array}{c}\text { Volume } \\
{\left[\mathrm{dm}^{3}\right]}\end{array}$ & $\begin{array}{c}\text { Weight } \\
{[\mathrm{kg}]}\end{array}$ & $\begin{array}{c}\text { Volume } \\
{\left[\mathrm{dm}^{3}\right]}\end{array}$ & $\begin{array}{c}\text { Weight } \\
{[\mathrm{kg}]}\end{array}$ & $\begin{array}{l}\text { Volume } \\
{\left[\mathrm{dm}^{3}\right]}\end{array}$ \\
\hline \multicolumn{2}{|c|}{ Cement } & 321.00 & 117.52 & 321.00 & 125.49 & 321.00 & 125.49 \\
\hline \multicolumn{2}{|c|}{ Fly ash } & 123.00 & 59.13 & 123.00 & 59.13 & 123.00 & 59.13 \\
\hline \multirow{4}{*}{ Aggregate } & CT1 & 446.88 & 163.10 & 440.96 & 160.93 & 438.09 & 159.89 \\
\hline & $\mathrm{CT} 2$ & 297.37 & 108.53 & 293.43 & 107.09 & 291.52 & 106.40 \\
\hline & CT3 & 253.01 & 92.34 & 249.66 & 91.12 & 248.04 & 90.52 \\
\hline & $\mathrm{CT} 4$ & 645.68 & 235.65 & 637.12 & 232.52 & 632.98 & 231.01 \\
\hline \multicolumn{2}{|c|}{ Mixing water } & 200.15 & 200.15 & 200.15 & 200.15 & 200.15 & 200.15 \\
\hline \multirow{2}{*}{\multicolumn{2}{|c|}{$\begin{array}{l}\text { Water in the aggregate } \\
\qquad \mathrm{B}[\mathrm{OH}]_{3}\end{array}$}} & 3.72 & 0.00 & 3.67 & 0.00 & 3.65 & 0.00 \\
\hline & & 0.00 & 0.00 & 0.00 & 0.00 & 4.44 & 1.28 \\
\hline \multicolumn{2}{|c|}{ S. Aluminate } & 0.00 & 0.00 & 0.00 & 0.00 & 8.88 & 2.57 \\
\hline \multicolumn{2}{|c|}{ Hyper plasticizer } & 3.70 & 3.22 & 3.70 & 3.22 & 3.70 & 3.22 \\
\hline \multicolumn{2}{|c|}{ Air } & 0.00 & 19.00 & 0.00 & 19.00 & 0.00 & 19.00 \\
\hline \multicolumn{2}{|c|}{ Total } & 2294.52 & 1000.00 & 2272.69 & 1000.00 & 2275.45 & 1000.00 \\
\hline
\end{tabular}

However, these free neutrons interact with the neutrons of the matter they entered and this interaction creates such particles as $\alpha, \beta, \gamma$ and X-rays. These secondary beams perform ionization by breaking the atoms, as the result of interaction.

Samples with $80 \times 80 \times 20 \mathrm{~mm}^{3}, 80 \times 80 \times 30 \mathrm{~mm}^{3}$ and $80 \times 80 \times 40 \mathrm{~mm}^{3}$ aspect ratios were prepared for each series of concrete, for neutron absorption experiment. Chemical components of each sample used in the calculations of neutron absorption are given in Table III.

If the intensity $N$ of a radiation beam decreases by amount of $\Delta N$ in an absorber with the thickness $\Delta x$, the intensity of the transmitted radiation is expressed as
$N=N_{0} \exp (-\mu x)$, where $N, N_{0}, x$ and $\mu$ are the intensity of the radiations entering the absorber, intensity of the radiations leaving the absorber, the thickness of absorber and linear absorption coefficient, respectively. Free neutrons are uncharged particles, formed during nuclear reactions. Thus they can easily enter each item, and they do not have direct ionizing properties.

\section{Results}

Findings related to the neutron absorption characteristics of concrete samples are presented in Table IV and in Figs. 1 and 2. 
TABLE III

The chemical components of the concrete samples.

\begin{tabular}{c|c|c|c}
\hline \hline $\begin{array}{c}\text { Chemical } \\
\text { components }\end{array}$ & PC & BAB & BSA \\
\hline $\mathrm{SiO}_{2}$ & 6.184 & 6.206 & 6.149 \\
$\mathrm{Al}_{2} \mathrm{O}_{3}$ & 1.538 & 1.609 & 1.530 \\
$\mathrm{Fe}_{2} \mathrm{O}_{3}$ & 0.997 & 0.982 & 0.992 \\
$\mathrm{CaO}$ & 8.653 & 7.774 & 8.606 \\
$\mathrm{MgO}$ & 0.413 & 0.816 & 0.410 \\
$\mathrm{Na}_{2} \mathrm{O}$ & 0.135 & 0.140 & 0.135 \\
$\mathrm{~K}_{2} \mathrm{O}$ & 0.177 & 0.194 & 0.176 \\
$\mathrm{SO}_{3}$ & 0.353 & 0.428 & 0.351 \\
$\mathrm{~B}_{2} 0_{3}$ & 0.000 & 0.146 & 0.104 \\
$\mathrm{CaCO}_{3}$ & 41.558 & 41.445 & 41.331 \\
$\mathrm{MgCO}_{3}$ & 30.763 & 30.679 & 30.594 \\
$\mathrm{H}_{2} \mathrm{O}$ & 8.590 & 8.650 & 8.606 \\
$\mathrm{LOI}^{\mathrm{Total}}$ & 0.398 & 0.570 & 0.396 \\
& 99.760 & 99.636 & 99.381
\end{tabular}

TABLE IV

Neutron absorption coefficients of concrete samples.

\begin{tabular}{|c|c|c|}
\hline Sample No. & $\begin{array}{c}\text { Thickness } \\
\text { [cm] }\end{array}$ & $\begin{array}{c}\text { Absorption coefficient } \mu \\
{\left[\mathrm{cm}^{-1}\right]}\end{array}$ \\
\hline PC-1 & 2.4 & 0.116304652 \\
\hline PC-2 & 3.4 & 0.099156904 \\
\hline PC-3 & 4.2 & 0.103002352 \\
\hline \multicolumn{2}{|c|}{$\mathrm{PC}_{\mathrm{avrg}}$} & 0.106154636 \\
\hline BAB-1 & 2.2 & 0.144636148 \\
\hline BAB-2 & 3.1 & 0.131643769 \\
\hline BAB-3 & 4.1 & 0.136993412 \\
\hline \multicolumn{2}{|c|}{$\mathrm{BAB}_{\mathrm{avrg}}$} & 0.137757776 \\
\hline BSA-1 & 2.5 & 0.106310744 \\
\hline BSA-2 & 3.4 & 0.110657491 \\
\hline BSA-3 & 4.3 & 0.103726118 \\
\hline \multicolumn{2}{|l|}{$\mathrm{BS}$} & 0.106898118 \\
\hline
\end{tabular}

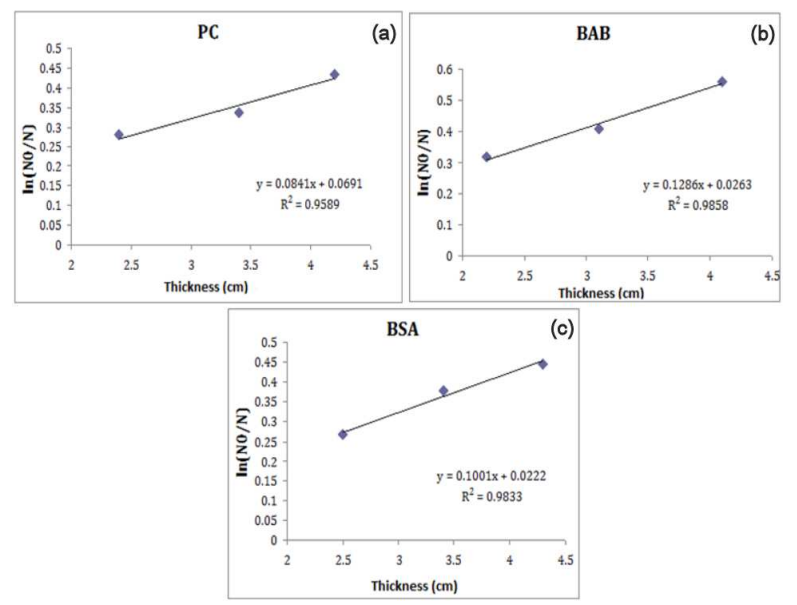

Fig. 1. Neutron absorption of the concrete as function of the thickness of the samples (a) PC, (b) BAB, (c) BSA.

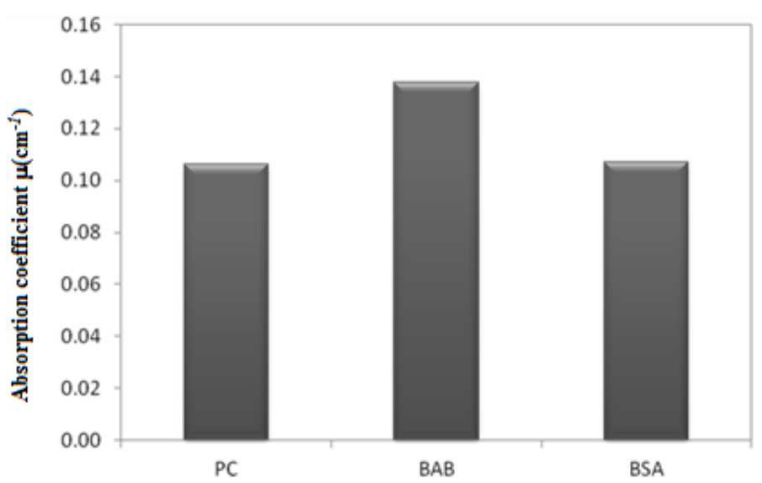

Fig. 2. Neutron absorption coefficients of concrete samples.

\section{Conclusions}

In this study, three series of concrete samples were produced using $\mathrm{B}_{2} \mathrm{O}_{3}$ additive material, boron modified active belite (BAB) and Portland cements. Neutron absorption coefficients of the produced three different types of concrete samples were obtained through experiments.

The following results were obtained:

- As the neutron absorption coefficients of concrete samples are compared, it is observed that BSA concretes had not gave the expected results, i.e. the obtained results for BSA concretes are almost the same as those for PC concretes.

- Neutron absorption coefficients of BAB concrete samples are higher than those for PC concretes by nearly $30 \%$.

- The proportion of $\mathrm{B}_{2} \mathrm{O}_{3}$ was $0.146 \%$ for $\mathrm{BAB}$ concretes while it was $0.104 \%$ for BSA concretes.

- It is concluded that the proportion of $\mathrm{B}_{2} \mathrm{O}_{3}$ is an efficient parameter for increasing the neutron absorption coefficient.

\section{References}

[1] I. Akkurt, C. Basyigit, S. Kilincarslan, B. Mavi, A. Akkurt, Cement Concrete Compos. 28, 153 (2006).

[2] I. Akkurt, H. Akyildirim, B. Mavi, S. Kilincarslan, C. Başyigit, Acta Phys. Pol. A 121, 144 (2012).

[3] F. Akarslan, T. Molla, İ. Akkurt, Ş. Kılınçarslan, I. Üncü, Acta Phys. Pol. A 125, 316 (2014).

[4] P.P. Power, W.G. Woods, Plant Soil 193, 1 (1997).

[5] M.F. Hawthorne, Angew. Chem. Int. Ed. Engl. 32, 950 (1993).

[6] Q. Sun, J. Li, J. Wang, Nucl. Engin. Design 241, 4341 (2011).

[7] M.H. Kharita, S. Yousef, M. Alnassar, Progr. Nucl. Ener. 53, 207 (2011).

[8] M. Davraz, Sci. Engin. Compos. Mater. 17, 1 (2010).

[9] M. Davraz, Ş. Kılınçarslan, E. Pehlivanoğlu, Acta Phys. Pol. A 125, 263 (2014). 